\title{
BEHAVIOR CHANGE AFTER HIV / AIDS DIAGNOSIS OF FEMALE SEXUALITY IN THE YOGYAKARTA CITY
}

\author{
Dwi Agustiana Sari ${ }^{1}$, Yanri Wijayanti Subronto², Wiwin Lismidianti ${ }^{3}$ \\ ${ }^{1}$ Program Studi IImu Keperawatan STIKES Guna Bangsa Yogyakarta \\ 2Dokter SMF Penyakit Dalam, Rumah Sakit Dr. Sardjito Yogyakarta. \\ ${ }^{3}$ Staf Pengajar, Program Studi Magister Keperawatan, Universitas Gadjah Mada \\ E-mail: dwiagustianasari@gmail.com
}

\begin{abstract}
Background: Anxiety, panic, inability to accept the conditions and low knowledge about good sexual behaviour can worsen HIV status.

Purpose: assess changes in sexual behavior before, the time of diagnosis, and current and causes.

Methode: Qualitative research phenomenological, semi-structured interviews with in dept interviews in 6 Participants women of reproductive age, diagnosed with HIV between 1-2 years before study, has been or ever married. Analysis using Collaizy.

Result: before diagnosis frequency: rarely and still routine, sexual behavior: oral, anal and masturbated to couples, sexual desire did not a decline. Causal factor that changes sexual behavior is a condition of pain, impaired self-image, increasing socio-economic burden, and change partners.

Dicussion: Hankins (1997) the majority of women after hear of HIV positive status will experience a significant disruption to the desire, arousal and orgasm function, is due to physiological and psychological factors. Recurrent pain during sexual intercourse can lead to avoidance. Psychosocial factors (stress, financial crisis, depression, anxiety) inhibit the production of liquid lubrication. Working full- time cause fatigue and decrease sexual desire for women with HIV.
\end{abstract}

Keywords : Women, HIV / AIDS, Sexual Behavior

\section{PENDAHULUAN}

Salah satu tujuan yang tercantum dalam Millennium Development Goals adalah menangani berbagai penyakit menular salah satunya infeksi Human Immunodeficiency Virus (HIV), target MDGs untuk HIV dan AIDS adalah menghentikan laju penyebarannya pada 2015. (Kementrian Kesehatan RI, 2009). Di Daerah Istimewa Yogyakarta (DIY), jumlah kasus HIV dan AIDS saat ini menempati urutan posisi ke-12 di antara provinsi lainnya. penghitungan dari Direktorat Pengendalian Penyakit dan
Lingkungan (Ditjen PP \& PL, 2013) bulan Juni 2013, mengungkap jumlah kasus HIV dan AIDS di DIY sebanyak 2.475 kasus, terdiri atas 1.693 kasus HIV dan 782 kasus AIDS. Dari faktor penyebaran, perilaku seksual berisiko dengan hubungan heteroseksual paling dominan di antara faktor lainnya, sebanyak 4.953 atau $48 \%$. Faktor risiko AIDS $80 \%$ juga melalui hubungan heteroseksual. Ini menunjukkan perilaku seksual berisiko masih menjadi penyebab utama penularan HIV. Prevalensi terjadinya kasus HIV pada perempuan pun terus mengalami peningkatan, tahun 2011 penderita HIV 
44\% adalah perempuan, tahun 2012 meningkat menjadi $43 \%$ dan di tahun 2013 meningkat menjadi 58\% (Kemenkes, 2013).

Perempuan lebih rentan tertular HIV 2,5 kali dibandingkan laki-laki dan remaja putra. Secara fisik, bentuk organ kelamin perempuan seperti bejana terbuka memudahkan virus masuk ke dalam vagina ketika berhubungan intim dengan lelaki positif HIV, melalui luka kecil, lecet atau masuknya cairan sperma ke vagina. Secara biologis permukaan (mukosa) alat kelamin perempuan yang lebih luas menyebabkan cairan sperma mudah terpapar ketika hubungan seksual. Selain itu, sperma yang terinfeksi HIV mempunyai konsentrasi virus yang lebih tinggi dibanding konsentrasi HIV pada cairan vagina (Dalimoenthe, 2011)

Dari studi pendahuluan yang dilakukan peneliti pada perempuan positif HIV di Sleman terdapat perubahan peran dan status perempuan setelah diagnosa HIV yaitu adanya kematian pasangan yang terlebih dahulu terkena HIV dan AIDS sehingga perempuan menjadi janda, tuntutan ekonomi keluarga yang menyebabkan perempuan harus bekerja ekstra untuk memenuhi kebutuhan dan tidak patuh dalam menggunakan kondom. Terjadinya penurunan hasrat seksual pada beberapa perempuan karena rasa takut, kecemasan akan kematian dan beban hidup yang berat, kondisi ini menuntut perempuan harus bekerja ekstra sehingga mengalami keletihan. Selain itu ada perempuan dengan HIV mengijinkan pasangannya mencari pasangan lain untuk menyalurkan hasrat seksualnya dan ini meningkatkan risiko penularan dan penyebaran HIV.

\section{METODE}

Jenis penelitian deskriptif dengan metode kualitatif dan pendekatan fenomenologi, bertujuan untuk mengungkapkan pengalaman perubahan perilaku seksualitas perempuan pasca Diagnosis HIV / AIDS. Penelitian dilakukan di wilayah Kota Yogyakarta, lokasi penelitian di LSM Victory Plus bulan Maret - Mei 2014.

Partisipan dipilih dengan teknik purposive sampling dengan pertimbangan: perempuan yang telah menikah atau pernah menikah dan didiagnosis positif HIV antara $1-2$ tahun sebelum penelitian, masih berusia produktif, bersedia dilakukan wawancara mendalam serta mampu menceritakan dengan baik pengalaman seksualitasnya. Pada penelitian ini partisipan penelitian yang dilibatkan sebanyak 6 (enam) orang partisipan, karena tidak ada lagi informasi yang dapat dijaring, maka penarikan sampel pun diakhiri. Peneliti berfungsi sebagai instrumen dibantu oleh recorder MP3 sebagai alat merekam dan pedoman wawancara. Wawancara yang digunakan semi-terstruktur dengan kategori in dept interview.

\section{HASIL DAN PEMBAHASAN}

Setelah informasi dari Partisipan menghasilkan data yang berulang atau mencapai saturasi, pengambilan data dihentikan. Sebanyak 6 orang Partisipan secara sukarela, dan memenuhi kriteria penelitian terlibat dalam penelitian ini.

Terdapat 8 tema utama dari hasil penelitian ini. Pertama: perubahan frekuensi hubungan seksual yang terjadi pada lima dari enam partisipan.Penelitian yang dilakukan oleh Scanavino (2010) dengan judul "sexual disfunction among people living with AIDS in Brazil" didapatkan hasil bahwa perempuan yang terdiagnosa HIV AIDS sebagian menghentikan hubungan seksual mereka sampai dengan dua belas bulan. Selain itu juga tingginya frekuensi ketidakaktifan dalam hubungan seksual dalam 12 bulan setelah diagnosa HIV / AIDS pada kelompok kasus (36\%). $28 \%$ nya melaporkan berhenti melakukan aktifitas seksual karena tidak ada partner seksual dalam beberapa bulan. 
Tabel 1 : Perubahan Frekuensi Hubungan Seksual Perempuan Partisipan pasca diagnosis HIV / AIDS di Kota Yogyakarta

\begin{tabular}{|c|c|c|}
\hline Kata Kunci & Kategori & Tema \\
\hline $\begin{array}{l}\text { dari hamil } 9 \text { bulan tahun } 2013 \text { itu sih sampe } \\
\text { sekarang saya nggak berhubungan (P 6) }\end{array}$ & $\begin{array}{l}\text { hubungan seks berhenti } \\
\text { total }\end{array}$ & \multirow{5}{*}{$\begin{array}{l}\text { Perubahan } \\
\text { frekuensi } \\
\text { hubungan } \\
\text { seksual }\end{array}$} \\
\hline sampe 1 tahun aku nggak berhubungan seks ( $P$ 1) & \multirow{3}{*}{$\begin{array}{l}\text { hubungan seks berhenti } \\
\text { sementara }\end{array}$} & \\
\hline $\begin{array}{l}\text { eee lama nek itu, iso maafke tapi nek dipegang } \\
\text { wegah, } 6 \text { bulan lebih itu, soale adaptasi sikek to, } \\
\text { males sikek }(P 4)\end{array}$ & & \\
\hline $\begin{array}{l}\text { saya sih setelah suami nggak ada tu pernah mbak } \\
\text { berhubungan..yaa saya sekitar berapa ya? } \\
\text { mungkin } 2 \text { bulan } 3 \text { bulan itu hoo ( } P \text { 2) }\end{array}$ & & \\
\hline $\begin{array}{l}\text { Kalo waktunya sih, jadi sebulan sekali, itupun } \\
\text { jarang gitu lho mbak }(P 3)\end{array}$ & $\begin{array}{l}\text { hubungar } \\
\text { jarang }\end{array}$ & \\
\hline
\end{tabular}

Sumber: Data Primer

Kedua : fungsi seksual pasca diagnosis HIV / AIDS pada lima dari enam partisipan mengalami gangguan. Gangguan fungsi seksual yang muncul adalah penolakan hubungan seksual, ketiadaan rangsang, penurunan hasrat, dan ketiadaan orgasme atau kenikmatan hubungan.

Tabel 2 : Gangguan Fungsi Seksual Perempuan Partisipan Pasca Diagnosis HIV / AIDS di Kota Yogyakarta

\begin{tabular}{|c|c|c|}
\hline Kata Kunci & Kategori & Tema \\
\hline $\begin{array}{l}\text { pokoknya aku udah gak mau lagi melakukan ini, }(P \text { 1) } \\
\text { Akuu positif HIV berarti aku harus stop sampe disini } \\
(P \text { 3) }\end{array}$ & \multirow{2}{*}{$\begin{array}{l}\text { Penolakan } \\
\text { hubungan } \\
\text { seksual (Sex } \\
\text { Aversion) }\end{array}$} & \multirow{10}{*}{$\begin{array}{l}\text { Gangguan } \\
\text { Fungsi } \\
\text { Seksual }\end{array}$} \\
\hline $\begin{array}{l}\text { sengit, nggak mau dipegang.... iso maafke tapi nek } \\
\text { dipegang wegah }(P \text { ) }\end{array}$ & & \\
\hline $\begin{array}{l}\text { ra nafsu sama sekali \& nggak mbak.. Aku merasa jijik } \\
\text { merasa kotor pada diri aku sendiri }(P 1)\end{array}$ & & \\
\hline $\begin{array}{l}\text { pikiran itu merasa terbebani mungkin, masih tetap di } \\
\text { benak saya itu lho penyakit kok punya penyakit kaya } \\
\text { gitu... jadinya mungkin nggak pernah merasakan } \\
\text { nikmat itu untuk melakukan hubungan itu cuma saya } \\
\text { menjalaninya sebagai sebagai kewajiban itu aja }(P 5)\end{array}$ & $\begin{array}{l}\text { Ketiadaan } \\
\text { rangsang } \\
\text { (Frigidity) }\end{array}$ & \\
\hline $\begin{array}{l}\text { Aku gak bergairan sama sekali aku ngerasa itu buat } \\
\text { apa sih kayak gitu kayaknya nggak penting buat aku } \\
\text { setelah aku terdiagnosa kayak gini ( }(P 1)\end{array}$ & \multirow{4}{*}{$\begin{array}{l}\text { Penurunan } \\
\text { Hasrat Seksual } \\
\text { (Hypoactive } \\
\text { Sex Desire) }\end{array}$} & \\
\hline $\begin{array}{l}\text { setelah B20 ini saya nggak nggak nggak begituu ( } P \text { 3) } \\
\text { Pengen tapi takut tu Iho..terangsang tapi piye yo? } \\
\text { Ho'o ora ho'o ora gitu ( } P \text { 4) }\end{array}$ & & \\
\hline $\begin{array}{l}\text { menurun gairahnya mungkin karena saya merasa jijik } \\
\text { dengan status saya ( } P \text { 5) }\end{array}$ & & \\
\hline $\begin{array}{l}\text { Sekarang sakit kaya gitu ngerasa udah nggak punya } \\
\text { rasa pengen hubungan }(P 6)\end{array}$ & & \\
\hline kalo capek yaa nggak maksimal (p 4) & & \\
\hline $\begin{array}{l}\text { jarang saya sampai orgasme itu jarang saya } \\
\text { sekarang itu atau mungkin karena status saya itu juga } \\
\text { saya nggak tau kok sekarang itu susah sekali }(P 5)\end{array}$ & $\begin{array}{l}\text { kenikmatan / } \\
\text { (Anorgasmia) }\end{array}$ & \\
\hline
\end{tabular}

Sumber : data primer 
Menurut penelitian yang dilakukan oleh Hankins (1997) menemukan bahwa sebagian besar perempuan setelah mendengar status HIV positive akan mengalami gangguan yang signifikan terhadap hasrat, gairah dan fungsi orgasmenya. Menurut penelitian dari Luzi (2009), prevalensi gangguan fungsi seksual yang terjadi pada perempuan dengan HIV positif antara lain rendahnya hasrat seksual, gangguan orgasme dan nyeri. Menurut Tracey (2010) Perempuan dengan HIV memiliki masalah seksual lebih besar dibandingkan perempuan tanpa HIV. Masalah seksual yang dialami perempuan dengan HIV antara lain gangguan hasrat, lubrikasi, orgasme, kepuasan dan nyeri.

Tema ketiga: adalah perubahan partner sex, Partisipan yang berubah partner seksualnya adalah yang tidak lagi memiliki pasangan tetap suami dan tidak semua partisipan dalam penelitian ini mengalami perubahan partner seksual. Dua orang partisipan yaitu partisipan 2 dan 3 menjalin hubungan dengan pacar, kenalan dan teman lama. Berikut ungkapan partisipan 2:

Tabel 3 : Perubahan partner seksual pada Perempuan Partisipan Pasca Diagnosis HIV / AIDS di Kota Yogyakarta

\begin{tabular}{|c|c|c|}
\hline Kata Kunci & Kategori & Tema \\
\hline $\begin{array}{l}\text { "... setelah suami nggak ada tu pernah mbak } \\
\text { berhubungan kan waktu itu juga aku ketemu } \\
\text { mbak }{ }^{* *} \text { itu kan, mbak }{ }^{* *} \text { juga ketemu di } \\
\text { Sardjito itu "Mbak'e sekarang dekat sama itu } \\
\text { "ya" gitu,, saya memang memang pernah } \\
\text { berhubungan..."P2 }\end{array}$ & $\begin{array}{l}\text { Berhubungan } \\
\text { seks dengan } \\
\text { kenalan }\end{array}$ & \multirow{2}{*}{$\begin{array}{l}\text { Perubahan } \\
\text { partner } \\
\text { sex }\end{array}$} \\
\hline $\begin{array}{l}\text { "...yaa aku punya pacar itu tu ee adek kelasku } \\
\text { hehehe berondong adek kelasku mbak, ... ya } \\
\text { aku pernah akuu melakukan hubungan seks } \\
\text { juga dengan dia ..." P3 }\end{array}$ & $\begin{array}{l}\text { Berhubungan } \\
\text { seks dengan } \\
\text { teman lama }\end{array}$ & \\
\hline
\end{tabular}

Sumber : data primer

Partisipan yang tidak mengalami perubahan partner sex adalah partisipan 1, 4, 5 dan 6 .

Masalah pengungkapan atau keterbukaan status dan negosiasi dalam penggunaan kondom dengan pasangan menjadi hal yang harus diperhatikan oleh petugas kesehatan dan perempuan dengan HIV. Transmisi virus HIV, keterbukaan status dengan partner seksual, potensial penularan secara vertikal ke janin, masalah terkait penggunaan obat terlarang, dapat mempengaruhi seksualitas. Sangat penting bagi perempuan dengan HIV / AIDS untuk menyampaikan masalah, pengalaman masa lalu dan pemeriksaan penunjang kepada petugas kesehatan untuk menindaklanjui permasalahan seksual tersebut, Fakoya (2007).

Tema keempat adalah kepatuhan menggunakan kondom. Penggunaan kondom bervariasi, ada yang patuh menggunakan kondom dan tidak patuh menggunakan kondom. Seperti diungkapkan dalam tabel berikut ini:

Tabel 4 : Kepatuhan penggunaan kondom Perempuan Partisipan Pasca Diagnosis HIV / AIDS di Kota Yogyakarta

\begin{tabular}{|c|c|c|}
\hline Kata Kunci & Kategori & Tema \\
\hline $\begin{array}{l}\text { “...dia sendiri nggak pernah mau pake gitu Iho, dianya } \\
\text { nggak mau ada, kayak gitu itu istilahnya, dia nggak } \\
\text { percaya kalo melakukan hubungan gitu ini bisa menular } \\
\text { itu juga nggak percaya gitu Iho....” (P 1) }\end{array}$ & \multirow[t]{2}{*}{ Tidak patuh } & \multirow{2}{*}{$\begin{array}{l}\text { Kepatuhan } \\
\text { menggunakan } \\
\text { kondom }\end{array}$} \\
\hline $\begin{array}{l}\text { "...pertama (terdiagnosis) iya, ... yoo pake tapi nek wes } \\
\text { kepepet yo nggak selanjutnya wes biasa lagi to? He'e } \\
\text { wes oke yo udah enggak kadang iya, ... yaudah kan }\end{array}$ & & \\
\hline
\end{tabular}


kadang pake kondom tapi kadang yo enggak nek wes kepepet kae enggak. Apalagi nek keluarr, kaliurang e yo, ... kadang iya kadang enggak, ... ya tergantungg moode hehe kalo saking terangsange yo es lupae mbak nggak pake tapi kalo masih inget yo pake...." (P 4)

"...iyaa padahal saya pake, trus 2 kali saya pernah melakukan 2 kali itu ya pake kondom, dulu saya sama orang ya yang 1 bulan setelah anu itu yo pake kondom teruss .(P 2)..."

"Kalo kamu mau melakukan hubungan seks sama aku

\section{Patuh}

menggunakan ya kita harus pake kondom " (P 3)

"....iya selalu...nggak berani kalau nggak makai kondom nggak berani..." (P 5)

Sumber : data primer

Penelitian Masfi'ah (2008) yang dilakukan di Kota Semarang menunjukkan bahwa sebagian besar subyek penelitian tidak melakukan hubungan seksual beresiko atau selalu menggunakan kondom karena melindungi diri dan pasangan, serta sebagai sarana KB. Sebagian kecil subyek penelitian melakukan perilaku seksual beresiko kepada pasangan karena merasa tidak nyaman dengan kondom, posisi tawar yang rendah, serta anggapan dampak buruk yang kecil pada hubungan sesama ODHA.

Ketidakpatuhan dalam menggunakan kondom dapat meningkatkan resiko penularan dan masalah kesehatan terhadap diri sendiri serta pasangan dengan HIV, hal ini didukung penelitian Gowan (2001) bahwa terjadi peningkatan penyakit menular seksual atau Sexually Transmitted
Disease pada orang dewasa yang terinfeksi HIV. Pengetahuan tentang manfaat kondom saja tidak cukup membuat seseorang patuh dalam penggunaan kondom. Banyak faktor yang mempengaruhi kepatuhan seseorang dalam penggunaan. Hasrat seksual, kepuasan, dan kenyamanan dalam hubungan dapat menjadi penghalang seseorang untuk menggunakan kondom.

Tema kelima adalah Gangguan gambaran diri. Gangguan gambaran diri yang muncul antara lain adalah perasaan rendah diri, merasa kotor dihadapan tuhan, merasa terbebani dengan status baru yang disandang, perasaan takut menulari pasangan, takut penyakitnya bertambah, dan takut menular ke janin jika sampai terjadi kehamilan. seperti diungkapkan dalam tabel berikut ini:

Tabel 5 : Gangguan Gambaran Diri Perempuan Partisipan Pasca Diagnosis HIV / AIDS di Kota Yogyakarta

\begin{tabular}{|c|c|c|}
\hline Kata Kunci & Kategori & Tema \\
\hline $\begin{array}{l}\text { Aku merasa jijik merasa kotor pada diri aku } \\
\text { sendiri (P1) }\end{array}$ & \multirow{2}{*}{ perasaan rendah diri } & \multirow{7}{*}{$\begin{array}{l}\text { Gangguan } \\
\text { Gambaran } \\
\text { diri } \backslash\end{array}$} \\
\hline $\begin{array}{l}\text { Didepan suami itu saya merasa kayak hina itu } \\
\text { jadinya saya malu (P5) }\end{array}$ & & \\
\hline $\begin{array}{l}\text { dihadapanNya itu saya malah merasa sangat } \\
\text { jijik }\left(\begin{array}{l}(5)\end{array}\right.\end{array}$ & $\begin{array}{l}\text { merasa kotor dihadapan } \\
\text { tuhan }\end{array}$ & \\
\hline $\begin{array}{l}\text { pikiran itu merasa terbebani mungkin, masih } \\
\text { tetap di benak saya itu Iho penyakit kok punya } \\
\text { penyakit kaya gitu (P 5) }\end{array}$ & $\begin{array}{l}\text { merasa terbebani dengan } \\
\text { status baru yang } \\
\text { disandang }\end{array}$ & \\
\hline Takute ngko tambah meneh ra yo (P 4) & \multirow{3}{*}{ perasaan takut } & \\
\hline Takute nanti pasangan aku bisa tertular ( $P$ 1) & & \\
\hline $\begin{array}{l}\text { Sampe hamil gimana takut pengaruh ke anak } \\
(P 2)\end{array}$ & & \\
\hline
\end{tabular}

Sumber : data primer 
Menurut penelitian dari Luzi (2009) Gangguan fungsi seksual dan perubahan perilaku seksual disebabkan oleh citra tubuh atau gambaran diri yang buruk dan kehidupan sosial. Lubrikasi dan orgasme terganggu dengan adanya gangguan citra tubuh / gambaran diri. Gangguan fungsi seksual dan perubahan perilaku seksual sangat berhubungan dengan sejumlah pengalaman pribadi dan kepuasan hubungan. Di Amerika disfungsi seksual memiliki hubungan yang kuat dengan perasaan rendah diri terhadap kondisi fisik dan kepuasan emosional serta adanya perasaan kurang bahagia. Disfungsi seksual lebih sering terjadi pada perempuan daripada laki - laki, sehingga berpotensi memiliki dampak yang lebih negatif terhadap kualitas hidup mereka. Menurut Bova (2003) banyak perempuan dengan HIV positif menghindari pembicaraan tentang aktifitas seksual dengan petugas kesehatan karena takut akan disalahkan karena tidak melakukan seks yang aman secara optimal.

$$
\text { Tema keenam adalah }
$$

meningkatnya beban sosial \& ekomoni perempuan dengan HIV positif. seperti diungkapkan dalam tabel berikut ini:

Tabel 6 : Peningkatan Beban Perempuan Partisipan Pasca Diagnosis HIV / AIDS di Kota Yogyakarta

\begin{tabular}{|c|c|c|c|}
\hline Kata Kunci & Kategori & & Tema \\
\hline $\begin{array}{l}\text { "...sudah ndak mikirkan hal } \\
\text { segitunyaa toh aku juga punya } \\
\text { anak- anak, aku harus memikirkan } \\
\text { masa depan anak - anak..." (P 1) }\end{array}$ & \multirow{3}{*}{$\begin{array}{l}\text { Mencari } \\
\text { anak }\end{array}$} & & \multirow{4}{*}{$\begin{array}{l}\text { Peningkatan } \\
\text { beban } \\
\text { perempuan }\end{array}$} \\
\hline $\begin{array}{l}\text { "...mbok wes lah ya sekarang itu } \\
\text { mikirnya anak - anak dulu ajaa } \\
\text { kalo yaa sama laki -laki itu } \\
\text { gampangane karo dipikir emboh } \\
\text { sesok - sesok..." (P 2) }\end{array}$ & & nafkah untuk & \\
\hline $\begin{array}{l}\text { "...saya mempunyai anaak dan } \\
\text { udah capek dengan anak dan saya } \\
\text { juga harus sibuk dengan pekerjaan } \\
\text { saya..." (P 3) }\end{array}$ & & & \\
\hline $\begin{array}{l}\text { "...saat ini cumaa ngelayanin } \\
\text { butuhnya suamii untuk sehari - } \\
\text { hari, kecuali untuk seksual belum } \\
\text { hehe... Ekonomi kan pokok saya, } \\
\text { saya tulang punggung, suami cuma } \\
\text { ikut ikut sama modalin..." (P 6) }\end{array}$ & $\begin{array}{l}\text { Tulang } \\
\text { keluarga }\end{array}$ & punggung & \\
\hline
\end{tabular}

Sumber : data primer

Bekerja penuh waktu seperti
mengurus anak seharian dapat menyebabkan kelelahan dan karenanya hasrat seksual pada perempuan menjadi rendah. Menurut Luzi (2009) faktor yang paling berhubungan dengan gangguan fungsi seksual pada perempuan adalah aspek psikososial terhadap infeksi HIV dan gambaran atau citra tubuh yang buruk. Dalam memenuhi kebutuhan ekonomi dan sosial menjadikan perempuan atau istri menjadi lupa akan kebutuhan seks mereka, mereka lebih menikmati hidup apabila kebutuhan sosial ekonomi dikatakan layak dan terpenuhi. (Scanavino, 2010)

Tema ketujuh yaitu keluhan fisik saat berhubungan seksual. Keluhan fisik yang muncul antara lain cape, seperti diungkapkan dalam tabel berikut ini: 
Tabel 7 : Keluhan fisik dalam hubungan Seksual Perempuan Partisipan HIV / AIDS di Kota Yogyakarta

\begin{tabular}{lll}
\hline Kata Kunci & Kategori & Tema \\
\hline “...aku cape, aku nggak mau & & \\
berhubungan.." $(P$ 1) & Cape & Keluhan \\
\hline “...Setelah nganu itu kok agak perih gitu & & $\begin{array}{l}\text { Fisik saat } \\
\text { jadie saya kan takut..." (P 2) }\end{array}$ \\
"...nggak nyaman bikin sakit kalo buat Nyeri & $\begin{array}{l}\text { Berhubungan } \\
\text { seks nyeri kalo misalnya keplenet - }\end{array}$ & Sex
\end{tabular}

Sumber : data primer

Sanford (2013) menemukan bahwa di pelayanan primer dilaporkan $20 \%$ perempuan dengan HIV positif mengeluh nyeri saat berhubungan seksual dengan partner mereka. Rasa nyeri atau pengalaman menyakitkan mungkin terjadi saat stimulasi alat kelamin atau mungkin terjadi segera setelah melakukan hubungan seksual. kondisi seperti infeksi panggul, infeksi saluran kemih atau bahkan infeksi pada vagina bisa menjadi penyebab dispaneuria tersebut. Meskipun penyebab dispaneuria lebih berasal dari gangguan organik, namun ada kemungkinan disebabkan karena komponen psikologis. Rasa sakit berulang ketika melakukan hubungan seksual dapat menyebabkan penghindaran, kurangnya gairah dan berakhir dengan kurangnya keinginan / minat dalam berhubungan seksual, Rahmawati (2011). Dispaneuria dalam banyak kasus dapat terjadi sebagai kombinasi antara faktor fisik dan psikososial.

Tema ke delapan yaitu perubahan wujud perilaku seksual

Tabel 8 : Wujud / bentuk perilaku Seksual Perempuan Partisipan HIV / AIDS di Kota Yogyakarta

\begin{tabular}{|c|c|c|}
\hline Kata Kunci & Kategori & Tema \\
\hline “... iyo yo diataas....” (P 4) & \multirow{4}{*}{ Sebelum Diagnosa } & \multirow{7}{*}{$\begin{array}{l}\text { Wujud } \\
\text { bentuk } \\
\text { Perilaku } \\
\text { Seksual }\end{array}$} \\
\hline $\begin{array}{l}\text { "... sama suami dulu pernah } \\
\text { lewat belakang..." (P 5) }\end{array}$ & & \\
\hline $\begin{array}{l}\text { “...posisinya ya posisi - posisi } \\
\text { seperti itulah posisi 69, posisi } \\
\text { atas bawah...." (P 5) }\end{array}$ & & \\
\hline $\begin{array}{l}\text { "...Cuma dicium - cium, belai - } \\
\text { belai, biar puass suaminya } \\
\text { walaupun nggak bisa } \\
\text { dimasukkan dari pada diaa cari } \\
\text { cewek lain, gitu..." (P 6) }\end{array}$ & & \\
\hline $\begin{array}{l}\text { “...ya biasa itu aja... atas } \\
\text { bawah...iya 69..." (P 5) }\end{array}$ & Saat Diagnosa & \\
\hline $\begin{array}{l}\text { "....lewat oral...." (P 3) } \\
\text { "....kadang di atass kadang yaa } \\
\text { gitu hehe...." (P 4) }\end{array}$ & \multirow[t]{2}{*}{ Saat ini } & \\
\hline $\begin{array}{l}\text { "....ya Cuma atas bawah thok...”" } \\
\text { (P 5) }\end{array}$ & & \\
\hline
\end{tabular}

Sumber : data primer

\section{KESIMPULAN}

Penyebab perubahan perilaku seksualitas pada Perempuan Partisipan pasca diagnosis HIV AIDS dapat disebabkan karena faktor fisik yaitu rasa cape dan nyeri saat behubungan, Faktor psikologis yaitu adanya gangguan 
gambaran diri, faktor sosial yaitu kehilangan pasangan tetap (suami) sehingga mengalami perubahan parner seksual dan meningkatnya beban sosial ekonomi perempuan setelah terdiagnosis dan budaya yang menganggap laki - laki lebih dominan, laki - laki sebagai pemimpin, kewajiban istri untuk melayani kebutuhan suami, perempuan yang tabu membicarakan seksualitas sehingga menggunakan bahasa isyarat dan kurangnya peran perempuan dalam keputusan menggunakan kondom.

\section{SARAN}

Berdasarkan hasil penelitian, maka diajukan saran bagi peneliti lainnya perlu melakukan penelitian lebih lanjut tentang seksualitas pasca diagnosis HIV / AIDS terutama perlunya digali lebih lanjut terkait keterbukaan status terhadap perempuan yang sering berganti pasangan, bagi perempuan dengan HIV / AIDS diharapkan untuk tidak ragu mengungkapkan permasalahan seksualitas dan perubahannya setelah diagnosis kepada petugas kesehatan terutama perawat agar bisa dicari penyelesaian dan tindak lanjut untuk menanganinya. LSM ataupun puskesmas diharapkan lebih pro aktif untuk memberikan informasi terkait gangguan seksual setelah diagnosis serta konseling dalam keamanan seks, serta bagi Tenaga Keperawatan diharapkan lebih memperhatikan aspek psikologis dan gangguan fungsi seksual pada perempuan saat merawat perempuan dengan HIV, serta tidak memberikan stigma negatif dan perawat juga harus memberikan perhatian terkait kepatuhan pemakaian kondom dan praktik perilaku seksual yang aman.

\section{DAFTAR PUSTAKA}

Aditya, (2005), Kerentanan Perempuan Terhadap HIV/AIDS: Melindungi Perempuan dari HIV/AIDS. J Perempuan. No. 43. Halaman 5.

Asfaw (2014). Contraceptive Use and Method Preference Among HIV Positive Women in Addis Ababa, Ethiopia: a Cross Sectional Survey. BMC Public Health Jun 6; 14: 566
Bell C, Richardson D, Wall M, Goldmeier D. (2006). HIV - Assosiated Female Sexual Disfunction - Clinical Experience and Literature Review.Int J STD AIDS, 17 (10): 706 -9 .

Bitzer. (2013). Sexual Desire and Hypoactive Sexual Desire Disorder in Women. Introducion and Overview. Standard Operating Procedure (SOP Part 1). J Sex Med. 10 (1): $36-49$.

Boyke. (2013). Hubungan Seks Ideal. Diakses tanggal 2 Agustus 2013, Pukul 08.50 WIB di alamat Web: https://id-

id.facebook.com/saya.dr.boyke/post s/466917956723040

Chakrapani, V. (2010). Prevalence and Contexts of Inconsistent Concom Use Among Heterosexual Men and Women Living with HIV in India: Implication for Prevention. Mary Ann Liebert J. vol 24 No. 1.

Dalimoenthe. (2011). Perempuan dalam Cengkraman HIV - ADS: Kajian Sosiologis Feminis Perempuan Ibu Rumah Tangga. Komunitas, Volume 5, No. 1. Hal: 41 - 48. Universitas Negeri Jakarta.

Familia, D. (2010). Seluk Beluk \& Fakta Disfungsi Seksual. Ar - Ruzz Media Group. Yogyakarta

Fakoya, H Lamba, N. Mackie, R Nandwani, A. Brown, EJ Bernard et al (2007). UK Guidelines for the Management of Sexual and Reproduction Health (SRH) of People Living with HIV Infection. British HIV Association (BHIVA).

Kinsey (1998). Sexual Behaviour In The Human Female. New Introduced By John Bancroft. Indiana University Press 601 Nort Morton Street, Bloomington, Indiana.

Luzy, G Guaraldi, R Murri, M De Paola, G Orlando et al (2009). Body Image is a Major Determinant of Sexual Dysfunction in Stable HIV - Infected Women. Antivir Ther; 14: 85 - 92.

Moleong, L. J (2013). Metodologi Penelitian Kualitatif Edisi 31. Bandung: PT. Rosdakarya

Pebody, R. (2008). Sexual difficulties in people living with HIV in France - 
result from a large representative sample of outpatient attending French Hospital. AIDS and Behaviour 12: 670 - 676 .

Sandford, Collier, Grosback (2013). Addresing Sexual Problem in HIV Primary Care: Experience From Patients. Arch Sex Behav. 42 (7): $1357-1368$.
Scanavino, M (2010). Sexual Dysfunction Among People Living With AIDS in Brazil. Clinics; 65 (5): 511 - 9

Tracey E, Louis, Schwartz, Golub, Cohen, Maki, et al (2010). HIV Infection and Women's Sexual Functioning. J Acquir Immune Defic Syndr. August 1: 54 (4): 360 - 367. 